\title{
Intensitas Penggunaan Media Sosial Instagram Dengan Motivasi Berprestasi
}

\author{
Riski Rahmawati, Musfichin, Mubarak \\ Universitas Islam Negeri Antasari Banjarmasin
}

\begin{abstract}
The purpose of this study was to find out the relationship of intensity of Instagram social media use with the achievement motivation at UIN Antasari Banjarmasin students. This study used a sample of 203 students. This type of research is quantitative research using correlation method. The results of the analysis of data on the intensity of social media use Instagram the highest frequency of subjects was in the medium category of 283 subjects with a percentage of 75,9\%, then in the high category of 47 subjects with a percentage of $12,6 \%$, and a low category of 43 subjects with a percentage of $11,5 \%$. While the results of the analysis of motivation to achieve the highest frequency of subjects were in the medium category of 228 subjects with a percentage of $61,1 \%$, then in the category in the high category as many as 78 subjects with a percentage of $20,9 \%$, and low category of 67 subjects with a percentage of $18 \%$. The value of $r$ is 0.292 (positive) so it can be concluded that there is a significant positive relationship between variable $X$ and variable $Y$, with the relationship rate between variables is relatively low. This correlation test using Pearson Product Moment technique is known that the calculated $r$ value is 0.292 with $p$ value 0.000 while the value of $r$ table at the level of significance of $5 \%$ with $N 373$ is 0.101 . Because the calculated $r$ value obtained $(0.292)>r$ table (sig $\%=0.101)$ ( $p$ value $<0.05)$, then the alternative hypothesis that states there is a relationship between the intensity of social media use Instagram with the motivation of achievement is acceptable.
\end{abstract}

Keywords: Intensity; social media Instagram; the achievement motivation.

\begin{abstract}
Abstrak
Tujuan penelitian ini adalah untuk mengetahui hubungan intensitas penggunaan media sosial Instagram dengan motivasi berprestasi pada mahasiswa UIN Antasari Banjarmasin. Penelitian ini menggunakan sample 373 Mahasiswa. Jenis penelitian ini adalah penelitian kuantitatif menggunakan metode korelasi. Hasil dari analisis data intensitas penggunaan media sosial Instagram frekuensi subjek terbanyak berada pada kategori sedang yaitu 283 subjek dengan persentase 75,9\%, kemudian pada kategori tinggi yaitu 47 subjek dengan persentase 12,6\%, dan kategori rendah sebanyak 43 subjek dengan persentase 11,5\%. Sedangkan hasil analisis dari motivasi berprestasi frekuensi subjek terbanyak berada pada kategori sedang yaitu sebanyak 228 subjek dengan persentase 61,1\%, kemudian kategori tinggi sebanyak 78 subjek dengan persentase 20,9\%, kategori rendah sebanyak 67 subjek dengan persentase 18\%. Nilai $\mathrm{r}$ adalah 0,292 (positif) maka dapat disimpulkan bahwa terdapat hubungan positif yang signifikan antara variabel X dan variabel $Y$, dengan tingkat hubungan antar variabel tergolong rendah. Uji korelasi ini menggunakan teknik Pearson Product Moment diketahui bahwa nilai $r$ hitung sebesar 0,292 dan $\mathrm{p}$ value 0,000 sementara nilai $\mathrm{r}$ tabel pada taraf signifikansi 5\% dengan N 373 ialah 0,101. Karena nilai $r$ hitung yang didapat $(0,292)>$ r
\end{abstract}


tabel $(\operatorname{sig} \%=0,101)$ ( $\mathrm{p}$ value $<0,05)$, maka hipotesis alternatif yang menyatakan ada hubungan antara intensitas penggunaan media sosial Instagram dengan motivasi berprestasi dapat diterima.

Kata kunci: Intensitas; media sosial Instagram; motivasi berprestasi.

Setiap individu memiliki kondisi internal yang sangat berperan dalam aktivitas dirinya dikehidupan sehari-hari. Salah satu kondisi internal tersebut ialah motivasi. Motivasi sendiri merupakan dorongan dasar yang menggerakkan seseorang untuk bertingkah laku(Nayantaka, 2017). Dorongan ini berada pada diri seorang individu yang menggerakkan untuk melakukan segala sesuatu yang sesuai dengan dorongan dalam dirinya. Bentuk dorongan pada manusia ada beragam jenisnya seperti dorongan untuk makan, dorongan untuk bekerja, dorongan untuk berprestasi dan sebagainya. Jauh sebelum itu, Al Qur'an sudah mendorong manusia untuk berprestasi dan bersungguh-sungguh dalam bekerja atau melakukan aktifitas seperti dalam Q.S Al-Insyirah /94: 5-8 yang berbunyi :

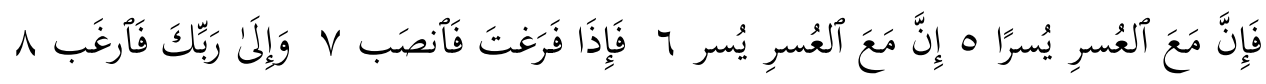

Artinya: "Karena sesungguhnya sesudah kesulitan itu ada kemudahan(5) Sesungguhnya sesudah kesulitan itu ada kemudahan (6) Maka apabila kamu telah selesai (dari sesuatu urusan), kerjakanlah dengan sungguh-sungguh (urusan) yang lain (7) Dan hanya kepada Tuhanmulah hendaknya kamu berharap (8)"

Dorongan untuk berprestasi sangat dibutuhkan bagi mahasiswa, karena umumnya bahwa nilai IPK menjadi salah satu tolak ukur prestasi mahasiswa sekarang ini. Sementara itu Departemen Pendidikan Nasional secara umum memberikan kriteria mengenai mahasiswa berprestasi, yaitu mahasiswa yang berhasil mencapai prestasi tinggi, baik prestasi akademik maupun non akademik, mampu berkomunikasi dengan baik, bersikap positif, serta berjiwa Pancasila. Secara khusus, kriteria mahasiswa berprestasi tersebut dapat dilihat dari nilai IPK, karya tulis ilmiah, dan juga aktif dalam kegiatan kurikuler, dan ekstra kurikuler (Haryani, 2014). Penurunan motivasi dalam proses belajar mengajar akan berdampak pada penurunan prestasi belajar. Hal ini sesuai dengan pendapat Notoatmodjo dalam skripsi Prizka Pahlawan bahwa motivasi sangat berhubungan dengan prestasi siswa atau mahasiswa yang duduk di 
bangku kuliah karena motivasi berhubungan dengan kebutuhan, motif dan tujuan yang sangat mempengaruhi kegiatan dan prestasi belajar (Pahlawan, 2018).

Seiring dengan perkembangan zaman, tuntutan prestasi mahasiswa semakin meningkat, hal ini tentunya juga harus diimbangi dengan sarana prasarana yang memadai guna membantu mahasiswa dalam mengembangkan aktivitas akademiknya. Salah satu contoh sarana yang dapat digunakan untuk membantu kegiatan akademik mahasiswa adalah internet yang mencakup berbagai informasi, situs hiburan, situs berita dan media sosial.

Instagram adalah salah satu dari sekian banyak media sosial yang populer di tengah masyarakat, baik anak-anak maupun orang tua tentu mengenal salah satu media sosial ini. Melalui Instagram masyarakat dapat mengunggah berbagai kegiatan, menulis keluh kesah, membagikan foto pribadi dan video singkat untuk disampaikan kepada semua orang melalui media sosial, bahkan banyak fitur-fitur baru yang diperbaharui untuk menunjang penggunanya seperti fitur siaran langsung dan Igtv. Survei menunjukkan bahwa Instagram merupakan platform media sosial terpopuler kedua, dengan 59\% pengguna online berusia 18-29 tahun (Yulianto, 2017). Hal ini menunjukan bahwa pengguna media sosial Instagram rata-rata adalah remaja dan dewasa awal yang memasuki atau sedang berada pada usia produktif.

Remaja merupakan fase peralihan dari masa anak-anak menuju dewasa, pada fase ini remaja masih mencari jati diri dan ingin membentuk citra diri mereka kepada masyarakat, sehingga akan menimbulkan perasaan ingin dikagumi dan mendapatkan validasi dari publik akan membuat remaja berupaya untuk menunjukkan eksistensi dirinya(Yulianto, 2017). Remaja menurut Piaget adalah berusia 11 tahun hingga dewasa, yang mana pada usia ini mencapai kemampuan berpikir sistematis, logis dan idealis terhadap hal-hal abstrak (Sarwono, 2008).

Mahasiswa adalah remaja yang akan menuju usia dewasa yang menggunakan media sosial bukan hanya sebagai sarana komunikasi dan informasi, akan tetapi juga sebagai pencarian jati diri, sarana menyalurkan emosi, hiburan dan motivasi. Safitri mengungkapkan bahwa penggunaan waktu yang berlebihan dalam menggunakan media sosial disinyalir akan berpengaruh pada kinerja mahasiswa dalam proses perkuliahan yang dapat mengganggu pencapaian prestasi akademik bagi para mahasiswa. Kendatipun demikian, menurut Prizka Pahlawan jika pemanfaatan media sosial ditujukan untuk pembelajaran akademik mahasiswa 
dengan tepat, maka sebaliknya penggunaan media tersebut akan menciptakan pencapaian prestasi akademik yang lebih baik walaupun dengan durasi yang cukup lama (Pahlawan, 2018).

\section{Metode}

Metode yang digunakan dalam penelitian ini adalah metode korelasi dengan menggunakan pendekatan kuantitatif. Subjek pada penelitian ini adalah mahasiswa UIN Antasari Banjarmasin angkatan 2018-2019 yang berjumlah 373 orang. Cara pengambilan sampel pada penelitian ini adalah teknik Non-Probability Sampling dengan menggunakan metode Purposive Sampling. Pengumpulan data dalam penelitian ini menggunakan skala likert yaitu skala intensitas penggunaan media sosial Instagram dan skala motivasi berprestasi. Skala intensitas penggunaan media sosial Instagram disusun berdasarkan aspek intensitas menurut Del Bario dan skala motivasi berprestasi disusun berdasar kepada aspek motivasi berprestasi menurut McClelland.

Tabel 1

Skala dan Aspek Penelitian

\begin{tabular}{lll}
\hline \multicolumn{1}{c}{ Skala } & & \multicolumn{1}{c}{ Aspek } \\
\hline Intensitas & - & Perhatian \\
Penggunaan & - & Penghayatan \\
Media Sosial & - & Durasi \\
Instagram & - & Frekuensi \\
& & \\
Motivasi & - & Tanggung jawab \\
Berprestasi & - & Memiliki tujuan yang realistic \\
& - & Berani mengambil dan memikul resiko \\
& - & Memanfaatkan umpan balik \\
& - & Melakukan rencana kerja yang menyeluruh dan \\
& & berjuang untuk merealisasikan tujuan. \\
\end{tabular}

Hasil uji validitas pada skala intensitas penggunaan media sosial Instagram didapatkan 16 item valid dan 7 item yang tidak valid dari total 23 item. Peneliti menggunakan 16 item yang valid untuk digunakan sebagai skala intensitas penggunaan media sosial Instagram. Kemudian hasil uji validitas motivasi berprestasi diperoleh hasil yakni sebanyak 30 item valid dan 4 item yang tidak valid dari total 34 item. Berdasarkan pada perhitungan uji 
reliabilitas dengan menggunakan program komputer SPSS 22.0 for windows diperoleh hasil untuk skala intensitas penggunaan media sosial Instagram $=0,679$ dan skala motivasi berprestasi $=0,880$. Artinya data yang digunakan untuk skala intensitas penggunaan media sosial Instagram dan motivasi berprestasi dapat dikatakan reliable atau dapat dipercaya dan dapat dilanjutkan untuk penelitian.

Selain itu teknik analisis data dalam penelitian ini yaitu menggunakan analisis statistik. Statistik yang digunakan untuk analisis data dalam penelitian ini adalah statistik deskriptif. pengujian hipotesis dilakukan menggunakan teknik Correlation Product Moment dari Karl Pearson karena terdiri atas dua variabel, dengan bantuan SPSS 22.0 For windows, untuk mengetahui apakah terdapat hubungan antara intensitas penggunaan media sosial instagram dengan motivasi berprestasi. Uji linearitas dilakukan dengan Test for Linearity menggunakan Compare Means dari SPSS 22.0 for Windows dengan taraf signifikan 0,05. Kedua variable dapat dikatakan linier apabila nilai signifikansi kurang dari 0,05.

\section{H a s i 1}

Hasil dari analisis deskriptif statistik untuk skala intensitas penggunaan media sosial Instagram dapat lihat dari nilai mean pada skala intensitas penggunaan media sosial Instagram yaitu 40,95 dan nilai standar deviasi adalah 5,271. Artinya peneliti dapat membuat kriteria tingkatan yang sesuai dengan pedoman yang sudah ada. Untuk lebih lengkapnya dapat dilihat pada tabel dibawah ini:

Tabel 2

Tingkatan Frekuensi Subjek Skala Intensitas Penggunaan Media Sosial Instagram

\begin{tabular}{lccc}
\hline & & & \\
Kategori & Norma & Frekuensi & Rentang Nilai \\
\hline$X<35,676$ & Rendah & 43 & $11,5 \%$ \\
$35,676 \leq X \geq 46,221$ & Sedang & 283 & $75,9 \%$ \\
$X>46,221$ & Tinggi & 47 & $12,6 \%$ \\
\hline
\end{tabular}

Berdasarkan kategorisasi yang telah dilakukan, maka dapat diketahui bahwa pada variabel intensitas penggunaan media sosial Instagram frekuensi subjek terbanyak berada pada 
kategori sedang yaitu 283 subjek dengan persentase 75,9\%, kemudian kategori tinggi yaitu 47 subjek dengan persentase 12,6\%, dan kategori rendah sebanyak 43 subjek dengan persentase 11,5\%. Hasil dari analisis deskriptif statistik untuk skala motivasi berprestasi didapat nilai mean pada 85,02 dan nilai standar deviasi adalah 8,281. Artinya peneliti dapat membuat kriteria tingkatan yang sesuai dengan pedoman yang sudah ada. Untuk lebih lengkapnya dapat dilihat pada table dibawah ini:

\section{Tabel 3}

Tingkatan Frekuensi Subjek Motivasi Berprestasi

\begin{tabular}{lccc}
\multicolumn{1}{c}{ Kategori } & Norma & Frekuensi & Rentang Nilai \\
\hline$X<76,739$ & Rendah & 67 & $18 \%$ \\
$76,739 \leq X \geq 93,301$ & Sedang & 228 & $61,1 \%$ \\
$X \geq 93,301$ & Tinggi & 78 & $20,9 \%$ \\
\hline
\end{tabular}

Berdasarkan kategorisasi yang telah dilakukan, maka dapat diketahui bahwa pada variabel motivasi berprestasi frekuensi subjek terbanyak berada pada kategori sedang yaitu sebanyak 228 subjek dengan persentase 61,1\%, kemudian kategori tinggi sebanyak 78 subjek dengan persentase 20,9\% dan kategori rendah sebanyak 67 subjek dengan persentase $18 \%$.

Pada penelitian ini, pengujian hipotesis dilakukan menggunakan teknik Correlation Product Moment dari Karl Pearson karena terdiri atas dua variabel, dengan bantuan SPSS 22.0 For windows untuk mengetahui apakah terdapat hubungan antara variabel $X$ yaitu intensitas penggunaan media sosial Instagram dengan variabel Y yaitu motivasi berprestasi. Adapun hasil uji korelasi dapat dilihat pada tabel dibawah ini: 
Tabel 4

Hasil Uji Korelasi Pearson Product Moment

Correlations

\begin{tabular}{cccc}
\hline & & $\begin{array}{c}\text { Intensitas } \\
\text { Penggunaan Media } \\
\text { Sosial Instagram }\end{array}$ & Motivasi Berprestasi \\
\hline Intensitas & Pearson & 1 & $.292^{* *}$ \\
Penggunaan & Correlation & & .000 \\
Media Sosial & Sig. (2-tailed) & & 373 \\
Instagram & $\mathrm{N}$ & 373 & 1 \\
\hline Motivasi & Pearson & $.292^{* *}$ & 373 \\
Berprestasi & Correlation & & \\
& Sig. (2-tailed) & .000 & \\
& $\mathrm{~N}$ & 373 & \\
\hline
\end{tabular}

Berdasarkan tabel tersebut menunjukkan bahwa signifikansi variabel intensitas penggunaan media sosial Instagram dan motivasi berprestasi sebesar 0,000 (taraf signifikansi < 0,05) hal ini menunjukan bahwa hipotesis dalam penelitian ini dapat diterima. Dan juga didapatkan hasil koefisien korelasi adalah 0,292 sehingga dapat dinyatakan bahwa hubungan antara variabel intensitas penggunaan media sosial Instagram dan motivasi berprestasi tergolong korelasi yang rendah. Karena 0,292 berada pada kekuatan hubungan koefisien korelasi rendah yakni antara 0,20 sampai 0,399. Angka koefisien korelasi berdasarkan kepada hasil uji korelasi product moment bernilai positif yaitu 0,292 yang artinya mempunyai hubungan yang bersifat searah yaitu semakin tinggi intensitas penggunaan media sosial Instagram makan motivasi berprestasi nya semakin tinggi pula.

Kemudian peneliti melakukan perhitungan uji determinasi dengan bantuan program komputer SPSS 22.0 for windows untuk mengetahui seberapa besae persentase sumbangan efektif pengaruh variabel intensitas penggunaan media sosial Instagram terhadap variabel motivasi berprestasi. Hasil uji tersebut dapat dilihat pada tabel berikut: 


\section{Tabel 5}

Hasil Uji Deteminasi

\section{Model Summary}

\begin{tabular}{|c|c|c|c|c|}
\hline Model & $\mathrm{R}$ & R Square & $\begin{array}{l}\text { Adjusted R } \\
\text { Square }\end{array}$ & Std. Error of the Estimate \\
\hline 1 & $.292^{a}$ & .085 & .083 & 7.932 \\
\hline
\end{tabular}

Dari tabel diatas menunjukkan besarnya nilai korelasi (R) yaitu sebesar 0,292. Selain itu, diperoleh pula koefisien determinasi (RSquare) sebesar 0,085 yang dapat diartikan bahwa pengaruh variabel bebas (intensitas penggunaan media sosial Instagram) terhadap variabel terikat (motivasi berprestasi) yakni sebesar 8,5\% dan sisanya yaitu 91,5\% dipengaruhi oleh faktor-faktor lain yang tidak diungkap dalam penelitian ini. Berikut rangkuman uji korelasi Pearson Product Moment.

Tabel 6

Rangkuman correlation product moment

\begin{tabular}{ccccc}
\hline Rxy & Rtabel & Sig & Keterangan & Kesimpulan \\
\hline 0,292 & 0,101 & 0,000 & Sig $<0,05$ & Signifikan \\
\hline
\end{tabular}

Berdasarkan hasil analisis pada tabel diatas dapat diketahui bahwa nilai $\mathrm{r}$ adalah 0,292. Sehingga berdasarkan hasil tersebut dapat dinyatakan bahwa hipotesis alternatif (Ha) yang menyatakan ada hubungan antara intensitas penggunaan media sosial Instagram dengan motivasi berprestasi pada mahasiswa UIN Antasari Banjarmasin dapat diterima. Sementara itu nilai koefisien korelasi sebesar 0,292 sehingga dapat dinyatakan bahwa hubungan antara variabel intensitas penggunaan media sosial Instagram dan motivasi berprestasi tergolong korelasi yang rendah.

\section{Pembahasan}

Berdasarkan pada hasil uji hipotesis yang telah dilakukan, didapatkan bahwa variabel intensitas penggunaan media sosial Instagram memiliki hubungan dengan motivasi berprestasi pada mahasiswa UIN Antasari Banjarmasin. Hasil ini sejalan dengan penelitian Prizka 
Pahlawan terkait dengan pemanfaatan media sosial Instagram sebagai media pembelajaran atau media untuk mencari informasi yang bersifat pengetahuan, dan pendidikan, menurutnya jika penggunaan media sosial ditujukan untuk pembelajaran ataupun kegiatan akademik lainnya oleh mahasiswa secara tepat, maka penggunaan media tersebut akan menciptakan pencapaian prestasi akademik yang lebih baik (Pahlawan, 2018).

Hal ini serupa dengan pendapat Ming Hun Lin, dkk dalam jurnal inovasi pendidikan dan pembelajaran sekolah dasar yang dikutip oleh Kosmas \& Jelvi menegaskan bahwa proses pembelajaran secara digital dapat membawa pengaruh yang positif terhadap motivasi siswa dan juga dapat meningkatkan hasil belajar (Kosmas S dan Jelvi M, 2019). Pendapat ini juga sejalan dengan hasil penelitian Irfan \& Siti tahun 2019 yang mengemukakan bahwa hasil analisis penggunaan media sosial secara bijak berpengaruh terhadap variabel motivasi belajar dan berprestasi siswa(M Irfan dan Siti N, 2019).

Berdasarkan hasil perhitungan korelasi menggunakan uji koefisien korelasi product moment dapat diketahui bahwa nilai $\mathrm{r}$ hitung adalah 0,292 dan p value 0,000 sementara itu nilai r tabel pada taraf signifikansi 5\% dengan N 373 adalah 0,101, jadi nilai r hitung yang diperoleh $(0,292)>\mathrm{r}$ tabel $(\operatorname{sig} \%=0,101)(\mathrm{p}$ value $<0,05)$. Sehingga berdasarkan pada hasil tersebut dapat dinyatakan bahwa hipotesis alternatif (Ha) diterima, yaitu terdaapat hubungan antara intensitas penggunaan media sosial Instagram dengan motivasi berprestasi pada mahasiswa UIN Antasari Banjarmasin. Sementara itu nilai koefisien korelasi sebesar 0,292. Kemudian diperoleh koefisien determinasi (RSquare) sebesar 0,085 yang dapat diartikan bahwa pengaruh variabel intensitas penggunaan media sosial Instagram terhadap variabel motivasi berprestasi yakni sebesar 8,5\% dan kemudian sisanya yaitu 91,5\% dipengaruhi oleh faktor-faktor lain yang tidak dapat diungkap dalam penelitian ini.

Terlihat dari rata-rata jawaban responden pada angket yang dibagikan melalu google form, sebanyak 203 orang responden dan 188 diantaranya mengikuti akun-akun yang berisi tentang informasi, ilmu pengetahuan dan akun yang mereka jadikan role model. Menurut data tersebut berarti mahasiswa cenderung memanfaatkan media sosial Instagram bukan untuk mencari hiburan saja melainkan juga sebagai media untuk mencari informasi yang berkaitan dengan ilmu pengetahuan dan media pembelajaran. 
Pada penelitian ini, peneliti juga melakukan perhitungan untuk mengetahui tingkat intensitas penggunaan media sosial Instagram pada mahasiswa UIN Antasari Banjarmasin. Peneliti menggunakan SPSS 22.0 for windows untuk membantu dalam perhitungan penelitian ini, adapun hasil dari perhitungan adalah nilai mean pada skala intensitas penggunaan media sosial Instagram adalah 40,95 dan nilai standar deviasi adalah 5,271. Selanjutnya dari hasil tersebut didapatkan kategori intensitas penggunaan media sosial Instagram frekuensi subjek terbanyak berada pada kategori sedang yaitu 283 subjek dengan persentase 75,9\%, kemudian kategori tinggi yaitu 47 subjek dengan persentase 12,6\%, dan kategori rendah sebanyak 43 subjek dengan persentase $11,5 \%$. Secara umum intensitas penggunaan media sosial Instagram pada mahasiswa UIN Antasari berada dalam kategori sedang. Hal ini mengacu pada tingkat persentase diatas dapat disimpulkan bahwa seluruh responden memberikan jawaban atas item pernyataan yang diajukan menunjukkan tingkat perilaku intensitas penggunaan media sosial.

Berdasarkan hasil uraian data tersebut, intensitas penggunaan media sosial Instagram pada mahasiswa UIN Antasari Banjarmasin lebih dominan berada pada kategori sedang. Sedang nya intensitas tersebut dapat terlihat dari jawaban responden yang menggunakan Instagram rata-rata adalah 1-3 jam per hari Menurut Ekasari dalam jurnal yang berjudul Dampak Sosial Ekonomi Masuknya Pengaruh Internet Dalam Kehidupan Remaja di Pedesaan, pengguna ini disebut dengan Medium users yaitu pengguna internet yang menghabiskan waktu antara 10 sampai 40 jam per bulan (Ekasari, 2012)

Adapun pengertian Intensitas penggunaan media sosial Instagram adalah suatu situasi atau aktivitas individu dalam menggunakan atau memakai media sosial khususnya instagram secara berulang-ulang dengan frekuensi tertentu. Instagram merupakan salah satu media sosial yang cukup dikenal di tengah masyarakat. Instagram adalah aplikasi untuk berbagi foto atau video dan layanan jejaring sosial online yang memudahkan penggunanya untuk mengambil gambar dan video dimanapun mereka berada hanya dengan menggunakan ponsel saja, dapat menerapkan filter digital, dan bahkan dapat berbagi hasilnya melalui berbagai layanan media sosial seperti Facebook, Twitter dan media lainnya yang terhubung dengan Instagram (Pahlawan, 2018). 
Dalam teori motivasi dan pembagiannya, penggunaan media sosial Instagram adalah salah satu bentuk motivasi ekstrinsik yang mana hal atau keadaan itu datang dari luar individu mahasiswa yang mendorongnya untuk melakukan sesuatu. Penggunaan media sosial Instagram termasuk faktor dari luar mahasiswa yang mempengaruhi motivasi berprestasi mereka.

Selanjutnya peneliti melakukan penelitian terkait tingkat motivasi berprestasi pada mahasiswa UIN Antasari Banjarmasin. Peneliti menggunakan SPSS 22.0 for windows untuk membantu dalam perhitungan penelitian ini, adapun hasil dari perhitungan dalam penelitian ini, nilai mean pada skala motivasi berprestasi ialah 85,02 dan nilai standar deviasi adalah 8,281. Selanjutnya dari hasil tersebut didapatkan kategori motivasi berprestasi dengan frekuensi subjek terbanyak berada pada kategori sedang yaitu sebanyak 228 subjek dengan persentase $61,1 \%$, kemudian kategori tinggi sebanyak 78 subjek dengan persentase 20,9\% dan kategori rendah sebanyak 67 subjek dengan persentase 18\%. Secara umum motivasi berprestasi pada mahasiswa UIN Antasari Banjarmasin berada dalam kategori sedang. Mengacu pada tingkat persentase diatas maka dapat disimpulkan bahwa seluruh responden memberikan jawaban atas item pernyataan yang diajukan menunjukkan tingkat perilaku motivasi berprestasi.

\section{Kesimpulan}

Hasil penelitian menunjukan bahwa tingkat intensitas penggunaan media sosial Instagram pada mahasiswa UIN Antasari Banjarmasin dominan berada pada kategori sedang yaitu 169 subjek dengan rata-rata penggunaannya adalah 1 jam perhari. Kategori intensitas penggunaan media sosial Instagram dengan frekuensi subjek terbanyak berada pada kategori kategori sedang yaitu 283 subjek dengan persentase 75,9\%, kemudian kategori tinggi yaitu 47 subjek dengan persentase 12,6\%, dan kategori rendah sebanyak 43 subjek dengan persentase 11,5\% . Adapun tingkat motivasi berprestasi didapatkan kategori sedang yaitu sebanyak 228 subjek dengan persentase 61,1\%, kemudian kategori tinggi sebanyak 78 subjek dengan persentase 20,9\% dan kategori rendah sebanyak 67 subjek dengan persentase 18\%. Dengan mengetahui hasil tersebut, motivasi berprestasi pada mahasiswa UIN Antasari lebih dominan pada kategori sedang. Kemudian berdasarkan hasil analisis data dengan menggunakan teknik 
Correlation Product Moment diketahui bahwa nilai $\mathrm{r}$ adalah 0,292 (positif) maka dapat disimpulkan bahwa variabel intensitas penggunaan media sosial Instagram dan variabel motivasi berprestasi memiliki hubungan positif, artinya semakin tinggi intensitas penggunaan media sosial Instagram maka semakin tinggi pula motivasi berprestasi pada Mahasiswa UIN Antasari dengan tingkat hubungan antar variabel tergolong rendah yaitu sebesar $8,5 \%$ dan sisanya yaitu 91,5\% dipengaruhi oleh faktor-faktor lain yang tidak diungkap dan dijelaskan dalam penelitian ini.

\section{Saran}

Adapun saran-saran yang dapat diberikan peneliti diantaranya yaitu bagi peneliti selanjutnya sebaiknya melakukan wawancara mendalam dengan responden untuk menggali lebih jauh lagi bagaimana hubungan intensitas penggunaan media sosial dengan motivasi berprestasi mereka. Serta peneliti selanjutnya bisa menghubungkan variabel intensitas dengan beberapa variabel lain seperti harga diri, citra diri dan lainnya. Bagi mahasiswa yang hidup dan besar di era teknologi seperti saat ini hendaknya menggunakan media sosial khususnya Instagram secara bijak dan benar, baik sebagai pendukung media pembelajaran, menjadi media penyalur hobi atau hanya sekedar media hiburan saja, serta selalu menjalankan kaidah atau aturan dalam bermedia sosial dengan benar. Bagi para pengajar, pemanfaatan media sosial dan media teknologi lainnya sebagai salah satu sarana pembelajaran adalah terobosan baru yang bisa dilakukan agar proses pembelajaran menjadi sangat bervariasi, serta secara langsung maupun tidak langsung dapat membantu mengawasi dan mengarahkan para mahasiswa atau peserta didiknya agar memanfaatkan media sosial bukan hanya untuk hiburan saja melainkan juga bisa digunakan untuk sesuatu yang lebih bermanfaat.

\section{Referensi}

Ekasari, D. (2012). Dampak Sosial Ekonomi Masuknya Pengaruh Internet Dalam Kehidupan Remaja di Pedesaan. Jurnal Sosiologi Pedesaan Departemen Sains Komunikasi Dan Pengembangan Masyarakat Fakultas Ekologi Manusia Institut Pertanian Bogor, (1), 57-71.

Haryani, R. (2014). Motivasi Berprestasi Pada Mahasiswa Berprestasi Dari Keluarga Tidak Mampu Secara Ekonomi. Jurnal Psikologi Pendidikan dan Perkembangan, 3(1). 
Kosmas S dan Jelvi M. (2019). Pengaruh Penggunaan Smartphone Terhadap Motivasi Belajar Siswa Sekolah Dasar di Kecamatan Mapanget, Kota Manado. Jurnal Inovasi Pendidikan Dan Pembelajaran Sekolah Dasar, (3).

M Irfan dan Siti N. (2019). Pengaruh Penggunaan Media Sosial (Medsos) Secara Positif Terhadap Motivasi Belajar Siswa SD Negeri Perumnas Kecamatan Rappocini Kota Makassar. Jurnal Publikasi Pendidikan, (9).

Nayantaka, J. (2017). Motivasi Berprestasi Mahasiswa Yang Berasal Dari Pulau Mandangin. Jurnal Psikologi Pendidikan, 4(3).

Pahlawan, P. (2018). Hubungan Durasi Penggunaan Media Sosial Dengan Motivasi Belajar Mahasiswa Angkatan 2015. Skripsi, Universitas Lampung, Lampung.

Sarwono, S. (2008). Psikologi Remaja. Rajagrafindo Persada.

Yulianto, M. (2017). Penggunaan Media sosial Instagram Dalam Pembentukan Indentitas Diri Remaja. Universitas Diponegoro.

\begin{tabular}{|l|l|l|l|l|}
\hline Submit & Review & Revisi & Diterima & Publis \\
\hline $16-12-2020$ & - & - & $22-04-2021$ & $22-04-2021$ \\
\hline
\end{tabular}

\section{Riski Rahmawati \\ Progran Studi Psikologi Islam \\ Fakultas Ushuluddin dan Humaniora \\ Universitas Islam Negeri Antasari Banjarmasin \\ Email : riskirahma1011@gmail.com}

